\title{
PENGARUH SERANGAN HAMA KUTU PUTIH (Phenacoccus manihoti Matile- Ferrero) TERHADAP PRODUKSI UBIKAYU (Manihot esculenta Crantz)
}

\section{THE EFFECT OF CASSAVA MEALYBUG (Phenacoccus manihoti Matile-Ferrero) ATTACK ON CASSAVA (Manihot esculenta Crantz) PRODUCTION}

\author{
Dicky Ashari Ramadhan $^{1 *}$, F.X. Susilo², Nur Yasin², \& I Gede Swibawa² \\ ${ }^{1}$ Jurusan Agroteknologi, Fakultas Pertanian, Universitas Lampung, Bandar Lampung, Indonesia \\ ${ }^{2}$ Jurusan Proteksi Tanaman, Fakultas Pertanian, Universitas Lampung, Bandar Lampung, Indonesia \\ *Email: ramadhandky@gmail.com \\ * Corresponding Author, Diterima: 21 Des. 2020, Direvisi: 15 Mar. 2021, Disetujui: 5 Mei 2021
}

\begin{abstract}
Cassava is one of the important food crops in Indonesia, but it has a mealybug (Phenacoccus manihoti Matile-Ferrero) problem. The mealybug attack can reduce cassava production. This study aims to 1) determine the level of mealybug attack and 2) determine the effect of mealybug attack on cassava production in South Lampung and Central Lampung. This research was conducted in three cassava plots in South Lampung and Central Lampung. Research activities in the first plot and the second plot were done in April 2018 - September 2018, and in August 2018, respectively while research in the third plot was done in January 2019 - March 2019. The mealybug attack was expressed by the number of cassava plants that showed a bunchy-top symptom(\%), while the production of cassava plants was expressed by the tuber weight and tuber number. The tuber weight and tuber number, attacked by mealybug versus healthy cassava plants, were analyzed using paired t tests at $1 \%$ or $5 \%$ significance level. The results of the study showed that the mealybug attack reduced cassava production in the Central and South Lampung regions. The rate of mealybug attack varied from 4,7\% to 8,7\%. The mean value of tuber weight from cassava plants attacked by the mealybug decreased $728,3 \mathrm{~g} / \mathrm{stem}$ while the mean value of tuber size decreased 50,5 g/tuber. The mean value of tuber number from cassava plants attacked by the mealybug decreased 2 tubers/stem.
\end{abstract}

Keywords: Attack, cassava, mealybug, tuber.

\begin{abstract}
ABSTRAK
Tanaman ubikayu merupakan salah satu tanaman pangan penting di Indonesia. Tanaman ubikayu mengalami serangan hama kutu putih (Phenacoccus manihoti Matile-Ferrero). Serangan hama kutu putih dapat menurunkan produksi ubikayu. Penelitian ini bertujuan untuk 1) mengetahui tingkat serangan hama kutu putih dan 2) mengetahui pengaruh serangan hama kutu putih terhadap produksi tanaman ubikayu di kawasan Lampung Selatan dan Lampung Tengah. Penelitian ini dilaksanakan di tiga pertanaman ubikayu di Lampung Selatan dan Lampung Tengah. Kegiatan penelitian di petak pertama berlangsung dari bulan April 2018 sampai September 2018, penelitian di petak kedua berlangsung pada bulan Agustus 2018, sedangkan penelitian di petak ketiga berlangsung dari bulan Januari 2019 sampai Maret 2019. Serangan hama kutu putih kutu putih dinyatakan dengan banyaknya tanaman ubikayu yang menunjukkan gejala bunchy-top sedangkan produksi tanaman ubikayu dinyatakan dengan
\end{abstract}


bobot umbi dan jumlah umbi ubikayu. Tanaman yang mengalami bunchy-top pada setiap baris atau gulud sampel diturus. Bobot umbi dan jumlah umbi pada tanaman ubikayu, yang terkena serangan hama kutu putih versus yang sehat dianalisis dengan uji t berpasangan pada taraf nyata $1 \%$ atau $5 \%$. Hasil penelitian menunjukkan bahwa tingkat serangan hama kutu putih menurunkan produksi ubikayu di kawasan Lampung Tengah dan Lampung Selatan. Tingkat serangan hama kutu putih bervariasi dari 4,7 \% sampai dengan 8,7 \%. Nilai tengah bobot umbi akibat serangan hama kutu putih berkurang sebanyak 728,3 g/batang. Nilai tengah ukuran umbi tanaman ubikayu yang terserang kutu putih berkurang sebanyak, 50,5 g/umbi. Nilai tengah jumlah umbi pada tanaman ubikayu yang terserang kutu putih berkurang sebanyak 2 umbi/batang.

Kata kunci : Kutu putih, serangan, ubikayu, umbi.

\section{PENDAHULUAN}

Tanaman ubikayu atau yang biasa disebut dengan singkong (Manihot esculenta Crantz) merupakan salah satu tanaman pangan penting di Indonesia. Hal ini dapat dilihat dari kandungan karbohidratnya yang tinggi pada umbinya. Menurut Soetanto (2008), kandungan karbohidrat dalam umbi ubikayu mencapai 34,7 gram/100gram. Bentuk olahan dari ubikayu ini dapat berupa makanan tradisional maupun modern, di antaranya mie, krupuk, tiwul instan, kue lapis, dan lain-lain (Balitbangtan, 2008).

Sejarah menyebutkan tanaman ubikayu awal mulanya berasal dari benua Amerika, yaitu di negara Brazil. Penyebaran ubikayu terjadi hingga mencapai berbagai negara, di antaranya benua Afrika (Madagaskar), Asia Tengah (India), Asia Timur (Tiongkok), dan Asia Tenggara. Pada tahun 1857 tanaman ubikayu masuk ke Indonesia (Soetanto, 2008).

Indonesia menduduki lima besar sebagai negara pengekspor ubikayu. Volume ekspor ubikayu Indonesia mencapai 19,9 juta ton, dengan posisi di bawah Nigeria (34,4 juta ton), Thailand (26,9 juta ton), dan Brasil (26,5 juta ton), tetapi satu tingkat di atas Kongo (15 juta ton). Aktivitas ekspor ubikayu ditunjang oleh permintaan yang besar akan gaplek dan tapioka (Ditkabi, 2008).

Provinsi Lampung adalah salah satu sentra produksi ubikayu di Indonesia. Pada tahun 2015 dengan luas lahan 279,34 ha Lampung memproduksi sebesar 7,39 juta ton ubikayu (BPS, 2016). Jumlah tersebut merupakan 30,8\% dari produksi ubikayu nasional. Lampung menduduki posisi pertama sebagai provinsi produsen ubikayu di Indonesia.

Tanaman ubikayu sering mendapat gangguan hama tanaman. Salah satu hama penting ubikayu ialah kutu putih. Hama ini menyerang dengan cara mengisap cairan daun dan batang. Kerusakan yang ditimbulkan pada tanaman adalah kerdil pada titik tumbuh (bunchytop), ruas batang pendek, dan daun baru yang tumbuh menjadi kecil serta mengerut (Saleh et al, 2013).

Kutu putih ubikayu merupakan hama baru di Indonesia. Di Indonesa kutu putih pertama kali ditemukan pada pertanaman ubikayu di daerah Jawa Barat pada akhir tahun 2010 (Muniappan et al, 2011). Menurut Abduchalek et al. (2017), survai yang dilakukan di pulau Jawa menunjukkan insidensi serangan kutu putih hampir mendekati 100\%. Menurut Parsa et al. (2012), kemampuan menyebar dari hama 
kutu putih cukup cepat, yaitu $150 \mathrm{~km} /$ tahun. Saat ini hama kutu putih sudah menyebar di seluruh provinsi di Indonesia (Balitkabi, 2016), termasuk di Lampung.

Separah apakah serangan hama kutu putih di Lampung? Berpengaruhkah serangan hama kutu putih itu terhadap produksi ubikayu? Untuk menjawab pertanyaan tersebut perlu dilakukan studi tentang hama kutu putih pada sentra-sentra pertanaman ubikayu di Lampung. Studi ini diarahkan untuk 1) mendatakan tingkat serangan hama kutu putih dan 2) mendatakan hasil umbi dari tanaman ubikayu, yang terkena serangan hama kutu putih versus hasil umbi dari tanaman ubikayu yang sehat, pada sentra pertanaman ubikayu di Lampung.

\section{BAHAN DAN METODE}

Penelitian ini dilaksanakan di tiga pertanaman ubikayu di Lampung Selatan dan Lampung Tengah. Lampung Selatan dan Lampung Tengah merupakan sentra produksi ubikayu di Lampung. Pertanaman yang pertama berada di daerah Tanjung Bintang, berlokasi Jl. Ir. Sutami, Desa Sukanegara, Kecamatan Tanjung Bintang, Kabupaten Lampung Selatan, dengan posisi geografis 5 $5^{\circ} 23^{\prime} 47,4648^{\prime \prime}$ LS dan $105^{\circ} 21^{\prime} 44,208^{\prime \prime}$ BT . Pertanaman kedua dan ketiga berada di Desa Purnama Tunggal, berlokasi Kecamatan Way Pengubuan, Kabupaten Lampung Tengah, dengan posisi geografis $4^{\circ} 23^{\prime} 47,4648^{\prime \prime}$ LS dan $105^{\circ} 21^{\prime}$ 44, 208" BT, 4 53'46, 2912" LS dan $105^{\circ} 8$ ' 58, 7076" BT. Kegiatan penelitian di petak pertama berlangsung dari bulan April 2018 sampai September 2018, penelitian di petak kedua berlangsung pada bulan Agustus 2018, sedangkan penelitian di petak ketiga berlangsung dari bulan Januari 2019 sampai Maret 2019.

Pengamatan di Desa Sukanegara, Kecamatan Tanjung Bintang, Kabupaten Lampung Selatan dilakukan dengan cara sebagai berikut. Pertanaman di Desa Sukanegara, berukuran 39m x 80m. Di pertanaman tersebut terdapat guludan-guludan tanaman ubikayu, terdiri atas 13 gulud pendek ( panjang $=70$ $\mathrm{m}$ dan lebar $=2 \mathrm{~m})$ dan 4 gulud panjang $($ panjang $=$ $80 \mathrm{~m}$ dan lebar $=2 \mathrm{~m}$ ). Setiap gulud diberi label, A, B, C, D, E, F, G, H, I, J, K, L, M, N, O, P, atau Q. Di setiap gulud terdapat 2 baris tanaman. Pada setiap gulud pendek terdapat 140 tanaman dan pada gulud panjang terdapat 160 tanaman. Klon ubikayu yang ditanam adalah UJ5.

Pengamatan di Desa Purnama Tunggal, Kecamatan Way Pengubuan, Kabupaten Lampung Tengah dilakukan dengan cara sebagai berikut. Di Desa Purnama Tunggal diamati dua petak pertanaman ubikayu. Petak pertanaman pertama berukuran $100 \mathrm{~m}$ x 200m. Di pertanaman tersebut terdapat 118 baris tanaman ubikayu. Pada setiap baris terdapat 322 tanaman. Klon ubikayu yang ditanam adalah Kasesart. Petak pertanaman kedua berukuran 100m x 100m. Di pertanaman tersebut terdapat 108 baris tanaman ubikayu. Pada setiap baris terdapat 230 tanaman. Klon ubikayu yang ditanam adalah C5, Kasesart, Thailand Moci, dan Thailand Emas.

Pada penelitian ini dilakukan sampling dengan cara mengambil pasangan tanaman sehat dengan tanaman mengalami bunchy-top (Gambar 1). Sampling pada pertanaman di Desa Sukanegara dilakukan di setiap gulud tanaman ubikayu, secara urut dari gulud A 
hingga gulud Q. Sebanyak 121 pasang tanaman yang mengalami bunchy-top pada setiap gulud diambil sebagai tanaman sampel. Tanaman yang tidak mengalami bunchy-top disebelahnya, diambil sebagai pasangannya. Pasangan tanaman sampel ubikayu yang telah ditentukan diberi label, dengan menggunakan plastik bening dan pita berwarna merah. Label plastik menunjukkan keterangan tanaman sampel yang sehat atau mengalami bunchy-top. Pita berwarna merah menunjukkan tanda tanaman ubikayu yang dijadikan sampel terserang hama kutu putih (bunchy-top).

Pengambilan tanaman sampel di Desa Purnama Tunggal 1 dan 2 ditentukan secara acak. Caranya dengan memilih 5 pasang baris secara acak dari 118 baris yang ada di dalam petak pertanaman (Purnama Tunggal 1) dan dari 108 baris (Purnama Tunggal 2). Pengacakan baris dilakukan menggunakan program excel. Ketika baris sampel tanaman ubikayu yang ditentukan secara acak adalah baris kedua, maka tanaman ubikayu baris pertama atau ketiga dipilih salah satu sebagai pasangan sampel dari baris tersebut. Penentuan baris pertama atau baris ketiga itu, dilakukan dengan pengundian menggunakan koin. Selanjutnya dilakukan penentuan tanaman sampel pada setiap baris tanaman sampel. Semua tanaman ubikayu pada baris sampel yang mengalami bunchy-top diambil sebagai tanaman sampel. Tanaman yang tidak bergejala bunchy-top di baris sebelahnya, diambil sebagai pasangannya.

Panen ubikayu dilakukan dengan waktu dan cara yang sudah ditentukan. Panen dilakukan terhadap tanaman sehat dan tanaman yang mengalami bunchytop dari setiap pasangan tanaman sampel. Ubikayu dipanen pada umur 10 bulan di pertanaman Desa Sukanegara, umur 7.5 bulan pada pertanaman Desa Purnama Tunggal 1, dan umur 8 bulan pada pertanaman Desa Purnama Tunggal 2 . Ubikayu dipanen dengan cara mencabut tanaman sampel dan tanaman pasangannya, ditimbang bobot umbinya, dan didatakan jumlah umbinya per batang tanaman.

Pengamatan tingkat serangan hama kutu putih dilakukan dengan cara menurus tanaman-tanaman ubikayu yang bergejala bunchy-top. Tanaman yang mengalami bunchy-top diturus pada setiap baris atau gulud sampel. Tingkat serangan hama kutu putih dihitung dengan rumus sebagai berikut

$$
I=\frac{a}{b} \times 100 \%
$$

dengan catatan, $\mathrm{a}=$ banyaknya tanaman di dalam baris atau gulud sampel yang mengalami bunchy-top dan b $=$ total tanaman di dalam baris atau gulud sampel.

Data bobot umbi dan jumlah umbi dianalisis dengan uji t berpasangan. Pengujian dilakukan pada taraf nyata $1 \%$ atau 5\%. Jumlah pasangan sampel tanaman di pertanaman ubikayu Desa Sukanegara adalah 121 pasang $(n=121)$, jumlah pasangan tanaman sampel di Desa Purnama Tunggal 1 adalah 76 pasang $(n=76)$, dan jumlah pasangan tanaman sampel di Desa Purnama Tunggal 2 adalah 100 pasang $(n=100)$. Nilai $\mathrm{t}_{\text {hit }}$ dihitung dengan rumus sebagai berikut (Billingsley \& Huntsberger, 1986)

$$
t_{\text {hit }}=\frac{\bar{D}}{s_{\bar{D}}}
$$

dengan catatan, $\bar{D}=\bar{Y}_{1-2}$ (selisih kedua nilai tengah contoh yang berpasangan). $S_{\bar{D}}=$ galat baku selisih kedua nilai tengah contoh yang berpasangan. 
Nilai $S_{\bar{D}}$ litentukan dengan rumus sebagai berikut (Susilo, 2013)

$$
S_{\bar{D}}=\frac{1}{\sqrt{n}} \sqrt{\frac{\sum\left(D_{i}-\bar{D}\right)^{2}}{n-1}}
$$

dengan catatan, $\mathrm{n}_{1}=\mathrm{n}_{2}=\mathrm{n}=$ ukuran contoh (banyak pasangan titik contoh). $=($ selisih pasangan variat ke-i).

\section{HASIL DAN PEMBAHASAN}

Hasil survai menunjukkan bahwa tingkat serangan hama kutu putih pada tanaman ubikayu rendah namun mempengaruhi produksi tanaman ubikayu tersebut. Tingkat serangan hama kutu putih di ketiga lokasi pertanaman ubikayu di Lampung itu kurang dari $10 \%$ namun serangan itu mengurangi produksi umbi di ketiga lokasi tersebut (Tabel 1, Tabel 2, dan Tabel 3). Bobot umbi pada tanaman yang mengalami bunchytop lebih rendah daripada bobot umbi pada tanaman sehat (Tabel 1 dan Tabel 2). Jumlahumbi pada tanaman yang mengalami bunchy-top juga lebih sedikit daripada jumlah umbi pada tanaman sehat (Tabel 3).

Di Lampung, produksi ubikayu turun sangat nyata oleh serangan hama kutu putih (bergejala bunchytop). Bobot umbi yang dihasilkan pada tanaman yang mengalami bunchy-top lebih rendah dibandingkan bobot umbi pada tanaman sehat. Tanaman ubikayu yang mengalami bunchy-top di kawasan ini mengalami penurunan bobot umbi antara 0,1 ton/ha (di Desa Sukanegara, Lampung Selatan) sampai dengan 2,0 ton/ ha (di Desa Purnama Tunggal, Lampung Tengah).

Turunnya produksi tersebut diperkirakan akibat proses fotosintesis pada tanaman yang mengalami bunchy-top tidak berjalan optimal. Hal itu diduga terkait dengan reduksi permukaan daun pada tanaman-tanaman yang bergejala bunchy-top sehingga

Tabel 1. Tingkat serangan hama kutu putih dan bobot umbi segar tanaman ubikayu.

\begin{tabular}{|c|c|c|c|c|c|c|}
\hline \multirow{2}{*}{ Lokasi } & \multirow{2}{*}{$\begin{array}{c}\text { Tingkat } \\
\text { serangan } \\
(\%)\end{array}$} & \multicolumn{2}{|c|}{$\begin{array}{l}\text { Bobot umbi } \\
\text { (g/batang) }\end{array}$} & \multirow{2}{*}{$\begin{array}{l}\text { Selisih@@@ } \\
\text { bobot umbi } \\
\text { (g/batang) }\end{array}$} & \multirow{2}{*}{ t-hit } & \multirow{2}{*}{$\begin{array}{c}\text { (n) Jumlah } \\
\text { pasangan tanaman } \\
\text { yang diamati }\end{array}$} \\
\hline & & Sehat & $\begin{array}{c}\text { Bunchy- } \\
\text { top }\end{array}$ & & & \\
\hline Desa Sukanegara $^{@}$ & 4,9 & 1648,3 & 818,1 & 830 & $8,03 * *$ & 121 \\
\hline Desa Purnama Tunggal 1@@ & 4,7 & 792,9 & 540,0 & 252 & $4,74 * *$ & 76 \\
\hline Desa Purnama Tunggal 2@@ & 8,7 & 2104,9 & 1001,5 & 1103 & $5,59 * *$ & 100 \\
\hline
\end{tabular}

Catatan: ${ }^{\circledR}=$ Tanjung bintang, Lampung Selatan; ${ }^{@} @=$ Way Pengubuan, Lampung Tengah; ${ }^{@} @=$ Antara tanaman yang sehat dengan tanaman yang bergejala keriting (mengalami bunchy-top); **= Nyata pada taraf $1 \%$.

Tabel 2. Tingkat serangan hama kutu putih dan bobot umbi per umbi tanaman ubikayu.

\begin{tabular}{|c|c|c|c|c|c|c|}
\hline \multirow{2}{*}{ Lokasi } & \multirow{2}{*}{$\begin{array}{c}\text { Tingkat } \\
\text { serangan } \\
(\%)\end{array}$} & \multicolumn{2}{|c|}{$\begin{array}{l}\text { Bobot umbi per } \\
\text { umbi (g/umbi) }\end{array}$} & \multirow{2}{*}{$\begin{array}{l}\text { Selisih@@@@ bobot } \\
\text { umbi per umbi } \\
\text { (g/umbi) }\end{array}$} & \multirow{2}{*}{ t-hit } & \multirow{2}{*}{$\begin{array}{c}\text { (n) Jumlah } \\
\text { pasangan } \\
\text { tanaman } \\
\text { yang diamati }\end{array}$} \\
\hline & & Sehat & $\begin{array}{c}\text { Bunchy- } \\
\text { top }\end{array}$ & & & \\
\hline Desa Sukanegara $^{@}$ & 4,9 & 252,5 & 183,4 & 69,2 & $4,54 * *$ & 121 \\
\hline Desa Purnama Tung & 4,7 & 99,0 & 82,3 & 16 & $3,07 * *$ & 76 \\
\hline Desa Purnama Tunggal 2@@ & 8,7 & 371,5 & 305,9 & 65,6 & $2,81 * *$ & 100 \\
\hline
\end{tabular}

Catatan: ${ }^{\circledR}=$ Tanjung bintang, Lampung Selatan; ${ } @=$ Way Pengubuan, Lampung Tengah; $@ @ @=$ Antara tanaman yang sehat dengan tanaman yang bergejala keriting (mengalami bunchy-top); $* *=$ Nyata pada taraf $1 \%$. 
Tabel 3. Tingkat serangan hama kutu putih dan banyaknya umbi segar tanaman ubikayu.

\begin{tabular}{|c|c|c|c|c|c|c|}
\hline \multirow{2}{*}{ Lokasi } & \multirow{2}{*}{$\begin{array}{l}\text { Tingkat } \\
\text { serangan } \\
(\%)\end{array}$} & \multicolumn{2}{|c|}{$\begin{array}{l}\text { Jumlah umbi } \\
\text { (umbi/batang) }\end{array}$} & \multirow{2}{*}{$\begin{array}{c}\text { Selisih@@@ } \\
\text { jumlah umbi } \\
\text { (umbi/batang) }\end{array}$} & \multirow{2}{*}{ t-hit } & \multirow{2}{*}{$\begin{array}{c}\text { (n) Jumlah } \\
\text { pasangan tanaman } \\
\text { yang diamati }\end{array}$} \\
\hline & & Sehat & $\begin{array}{c}\text { Bunchy- } \\
\text { top }\end{array}$ & & & \\
\hline Desa Sukanegara $^{@}$ & 4,9 & 6,6 & 4,5 & 2,0 & $7,12 * *$ & 121 \\
\hline Desa Purnama Tunggal 1@@ & 4,7 & 8,2 & 6,7 & 1,5 & $3,15^{* *}$ & 76 \\
\hline Desa Purnama Tunggal 2@@ & 8,7 & 5,4 & 2,9 & 2,5 & $7,91 * *$ & 100 \\
\hline
\end{tabular}

Catatan: ${ }^{\circledR}=$ Tanjung bintang, Lampung Selatan; ${ }^{\circledR}=$ Way Pengubuan, Lampung Tengah; $@ @ @=$ Antara tanaman yang sehat dengan tanaman yang bergejala keriting (mengalami bunchy-top); **= Nyata pada taraf $1 \%$.
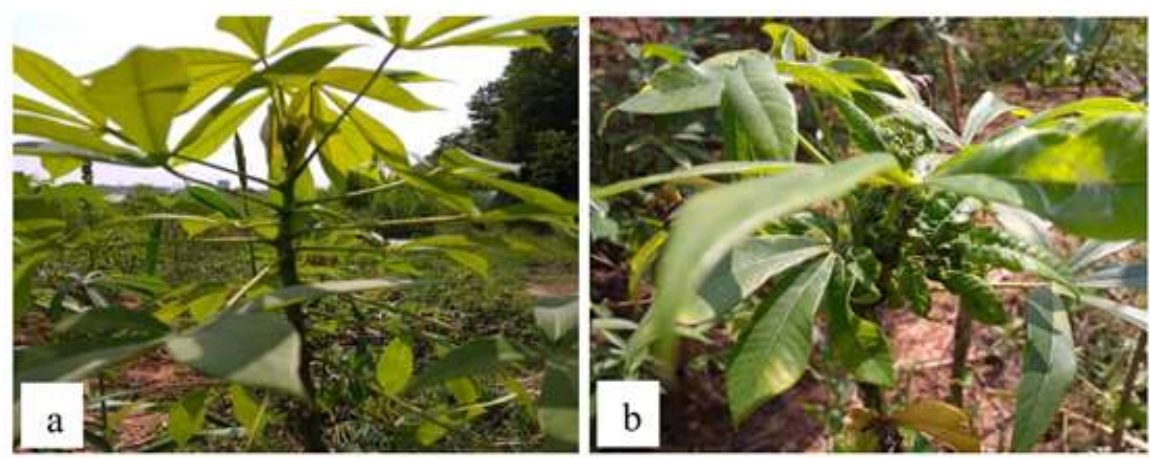

Gambar 1. (a) Tanaman ubikayu yang sehat dan (b) tanaman ubikayu yang mengalami bunchy-top.

fotosintat yang dihasilkan untuk pembentukan umbinya pun berkurang. Tonglum et al. (2001) menyatakan tanaman ubikayu yang terkena bunchy-top mengalami penurunan produksi akibat berkurangnya fotosintat yang diperlukan untuk pertumbuhan dan perkembangan tanaman

Variasi penurunan produksi ini diduga terkait juga dengan waktu tanam ubikayu. Serangan hama kutu putih dapat terjadi sejak dini dan meningkat pada saat musim kemarau. Di Desa Purnama Tunggal 2 ubikayu ditanam saat musim kemarau yaitu pada bulan Juli 2018, sedangkan di Desa Sukanegara ditanam pada bulan November 2017 dan Desa Purnama Tunggal 1 pada bulan Januari 2018 di saat musim hujan. Wardani (2015) menyatakan serangan hama kutu putih akan meningkat pesat saat musim kemarau dan puncaknya berada di bulan September-Oktober. Selain itu Wardani (2015) juga menyatakan tanaman ubikayu yang terserang kutu putih sejak masih muda menghasilkan bobot umbi yang jauh lebih sedikit.

Klon ubikayu yang ditanam diduga juga mempengaruhi variasi penurunan produksi ini. Setiap klon ubikayu memiliki ketahanan terhadap serangan hama yang berbeda-beda. Ketahanan klon ubikayu terhadap serangan hama dipengaruhi oleh kandungan senyawa sianida yang terkandung di dalamnya. Calatayud et al. (1994) menyatakan senyawa sianida dalam tanaman ubikayu merupakan fagostimulan bagi hama kutu putih yang mampu meningkatkan populasinya. Semakin tinggi kandungan senyawa sianida dalam suatu klon ubikayu maka semakin rentan pula klon itu terhadap serangan hama kutu putih. 
Klon ubikayu yang ditanam pada ketiga lokasi mengalami penurunan produksi yang berbeda. Klon ubikayu C5, Kasesart, Thailand Moci, dan Thailand Emas pada Desa Purnama Tunggal 2 merupakan klon yang lebih banyak berkurang bobot umbi dan banyaknya umbi, sedangkan klon ubikayu Kasesart pada Desa Purnama Tunggal 1 merupakan klon yang lebih sedikit berkurang. Hal ini diperkirakan bahwa klon C5, Thailand Moci, dan Thailand Emas memiliki kadar sianida yang lebih tinggi dibandingkan kadar sianida pada klon Kasesart. Soysouvanh \& Siri (2013) menyatakan klon Kasesart memiliki ketahanan terhadap serangan hama kutu putih.

Begitu pula klon ubikayu UJ5 pada Desa Sukanegara juga cukup banyak berkurang bobot umbi dan banyaknya umbi. Bobot umbi dan banyaknya umbi yang berkurang pada klon UJ5 mengalami perbedaan yang tidak besar dengan bobot umbi dan banyaknya umbi pada klon C5, Thailand Moci, dan Thailand Emas di Desa Purnama Tunggal 2. Hal ini diperkirakan bahwa kadar sianida klon UJ5 mendekati kadar sianida pada klon C5, Thailand Moci, dan Thailand Emas. Wardani (2015) menyatakan klon UJ5 memiliki kadar sianida yang tinggi yang lebih sesuai dengan peningkatan populasi hama kutu putih.

\section{KESIMPULAN}

Dari penelitian ini dapat disimpulkan sebagai berikut. Tingkat serangan hama kutu putih menurunkan produksi ubikayu di kawasan Lampung Tengah dan Lampung Selatan. Tingkat serangan hama kutu putih bervariasi dari $4,7 \%$ sampai dengan $8,7 \%$. Nilai tengah bobot umbi akibat serangan hama kutu putih berkurang sebanyak 728,3 g/batang. Nilai tengah ukuran umbi tanaman ubikayu yang terserang kutu putih berkurang sebanyak, 50,5 g/umbi. Nilai tengah jumlah umbi pada tanaman ubikayu yang terserang kutu putih berkurang sebanyak 2 umbi/batang.

\section{DAFTAR PUSTAKA}

Abduchalek, B., Rauf, A., \& Pudjianto. 2017. Kutu putih singkong, Phenacoccus manihoti Matile-ferrero (Hemiptera: Pseudococcidae): persebaran geografi di pulau jawa dan rintisan pengendalian hayati.J.HPT Tropika.17(1): 1-8.

Balitbangtan (Balai Penelitian dan Pengembangan Pertanian). 2008. Teknologi Budidaya Ubi Kayu. Balitbangtan. Bandar Lampung.

Balitkabi (Balai Penelitian Kacang dan Umbi). 2016. Pedoman Budidaya Ubi Kayu di Indonesia. IAARD Press. Jakarta.

BPS (Badan Pusat Statistik). 2016. Statistik Daerah Provinsi Lampung. https://www.bps.go.id. Diakses pada tanggal 2 Agustus 2018.

Billingsley, P. \& Huntsberger, D. V. 1986. Statistical Inference for Management and Economics. Allyn \& Bacon, Boston.

Calatayud, P. A., Rahbe, Y., Delobe1, B., KhuongHuu, E., Tertuliano, M., \& Le Ru, B. 1994. Infhence of secondary compounds in the floem sap of cassava on expression of antibiosis towards the mealybug Phenacoccus manihoti. Entomol exp appl. 72: 47-57.

Direktorat Budidaya Kacang-kacangan dan Umbiumbian (Ditkabi). 2008. Vademikum Ubikayu. $26 \mathrm{~h}$. 
Muniappan, R., Shepard, B. M., Watson, W., Carner, G. R., Rauf, A. Sartiami, D., Hidayat, P., Afun, J. V. K., Goergen, G., \& Ziaur, R. A. K. M. 2011. New records of invasive insect (Hemiptera: Sternorrhyncha) in Southeast Asia and West Africa. J. Agric Urban Entomol. 26(4):167-174.

Parsa, S., Kondo, T., \& Winotai, A. 2012. The Cassava Mealybug (Phenacoccus manihoti) in Asia: First Records, Potential Distribution, and an Identification Key. Plos One. 7(10).

Saleh, N. M., Rahayu, S.W., Indiati, B.S., Radjit, S., \& Wahyuningsih. 2013. Hama, Penyakit, dan Gulma pada TanmanUbi Kayu. IAARD Perss. Jakarta.

Soetanto, N. E. 2008. Tepung Kasava dan Olahannya. Kanisius. Yogyakarta.

Soysouvanh, P. \& Siri, N. 2013. Population abundance of pink mealybug, Phenacoccus manihoti on four cassava varieties. J. Khon Kaen Agr. 41(1): 149-153.

Susilo, F.X. 2013. Aplikasi Statistika untuk Analisis Data Riset Proteksi Tanaman. Anugrah Utama Raharja. Bandar Lampung. $168 \mathrm{~h}$.

Tonglum, A., Suriyanapan, P., \& Howeler, R. H. 2001. Cassava agronomy research and adoption of improved practices in Thailand - Major achievement during the past 35 years. Cassava's Potential in Asia in the 21st Century: Present Situation and Future Research and Development Needs. Proc. of the Sixth Regional Workshop held in Ho Chi Minch City, Vietnam: 228-258.

Wardani, N. 2015. Kutu putih ubi kayu, Phenacoccus manihoti Matile-Ferrero (Hemiptera: Pseudococcidae), hama invasif baru di Indonesia. Disertasi. Institut Pertanian Bogor. Bogor. 